\title{
Jurnal Teknologi Reaktor Nuklir

\section{Bandung TRIGA 2000 Reactor Power Analysis as a Function of the Number of Fuel Elements and the Power Peaking Factor}

\author{
Sudjatmi K. Alfa ${ }^{{ }^{*}}$, Endiah Puji Hastuti ${ }^{2}$, Prasetyo Basuki ${ }^{1}$, Santiko T. Sulaksono ${ }^{1}$, Rian Fitriana $^{1}$ \\ ${ }^{1}$ Center for Applied Nuclear Science and Technology - BATAN, Jalan Tamansari No. 71 Bandung 40132, Indonesia \\ ${ }^{2}$ Center for Nuclear Reactor Technology and Safety - BATAN, Bld 80 PUSPIPTEK Area, Serpong, South Tangerang, 15310, Indonesia
}

\section{ARTICLE INFO}

Article history:

Received: 14 May 2020

Received in revised form: 1 June 2020

Accepted: 2 June 2020

Keywords:

TRIGA 2000

Fuel Element

Power peaking factor

DNBR

Boiling

\begin{abstract}
A B S T R A C T
The reactivity value of the Bandung TRIGA 2000 reactor core has decreased over time, so the power generated by the reactor is also getting smaller, despite the control rod position is fully withdrawn. Therefore, it is necessary to reshuffle and refuel the fuel element to increase the excess reactivity by considering the safety parameters, such as axial and radial power peaking factors, $\mathrm{DNBR}, \mathrm{dT}_{\text {sat }}$, and temperature on the cladding and in the center of the fuel element. The analyzed reactor safety parameters are the number of fuel elements, which varied at 105,110 , and 115 elements, as well as power peaking factor, which varied at $1.55,1.65,1.75,1.85$, and 1.95 . The calculations were done using MCNP and COOLOD-N2 programs. If DNBR $\approx 1.3$ is determined as the safety limit for the operation of the Bandung TRIGA 2000 reactor, at PPF 1.95 (105, 110, and 115 fuel elements), it can be considered to operate the reactor at the power of $600-700 \mathrm{~kW}$. However, at PPF of 1.75 (105, 110, and 115 fuel elements), the reactor can be operated at the power of 700-800 kW, and at PPF of $1.55(105,110$, and 115 fuel elements), the reactor can be considered for operation at the power of $800-900 \mathrm{~kW}$. The results of these calculations can be used for consideration in determining the operating limits of the Bandung TRIGA 2000 reactor.
\end{abstract}

\section{INTRODUCTION}

The pretension to cease the production of TRIGA fuel elements by the manufacturer of TRIGA reactor fuel elements, CERCA/TRIGA International [1], made the Bandung TRIGA 2000 reactor operating agency, which owns limited fuel elements, to carefully calculate the implementation of core management. The basic principle of core management, particularly reshuffle and refuel, is to increase the excess reactivity by considering other safety parameters, such as shutdown margins and both axial and radial power peaking factors. The main goal of fuel management is to obtain the most

\footnotetext{
* Corresponding author

E-mail: sudjatmi@batan.go.id

DOI: $10.17146 / \mathrm{tdm} .2020 .22 .2 .5888$
}

optimal reactivity along with the most economical use of fuel [2]. The reactivity value of the Bandung TRIGA reactor core has decreased over time, so the power generated by the reactor is also getting smaller, despite the control rod position is fully withdrawn. Therefore, it is necessary to reshuffle and refuel the fuel elements.

The pattern of addition or removal of the fuel element must consider the neutronic aspect which includes the critical mass of uranium, distribution of the neutron flux in each fuel element, as well as thermalhydraulics aspect which includes the ratio of total radial and axial power peaking and also DNBR. This is important as it is closely related to the safety of the reactor. In addition, due to critical heat fluxes, the design of a water-cooled reactor requires sufficient safety margins. 
As the name implies, TRIGA reactor is used for training, research, and production of radioisotopes for various fields, such as medicine and industry. Bandung TRIGA 2000 reactor is an open pool, light water-cooled reactor, typical of the TRIGA Mark II reactor. The core is located near the bottom of the water-filled aluminum tank with a diameter of $198 \mathrm{~cm}$ and depth of $725 \mathrm{~cm}$. It currently holds 97 fuel elements, 3 fuel element control rods, 2 control rods without fuel element, and 5 instrumented fuel elements (IFE). The reactor core is in hexagonal arrangement and surrounded by graphite reflector. Each fuel element consists of a zirconium rod surrounded by a homogeneous solid mixture of UZrH $(8.5 \% \mathrm{U})$ with low-enriched U235 (19.7\% of U235), further encased within a stainless steel cladding [3].

TRIGA reactor is the only nuclear reactor in this category that offers true "inherent safety" rather than relying on "engineered safety." This owes to the unique properties of GA's uranium-zirconium hydride fuel, which provides incomparable safety characteristics. The fuel elements provides a very high negative prompt temperature coefficient, the main reason of the high inherent safety behavior of the TRIGA reactors. It also permits flexibility in siting, with minimal environmental effects [3,4].

In a typical TRIGA reactor, the entire fuel elements are cooled by single phase convection as long as the maximum wall temperature is kept below that is required to initiate boiling. However, at higher power level, in the inlet and outlet regions of the core, where the heat fluxes are the lowest, the channels are cooled by single phase convection. Meanwhile, in the central region, where the axial heat flux is the highest, heat transfer is predominantly in the form of subcooled boiling [4].

The TRIGA MARK II - CNESTEN reactor in Morocco is a TRIGA reactor designed to operate with the power of $2 \mathrm{MW}$, using natural convection cooling and minimum DNBR value higher than 1.6. The research on this reactor shows that the maximum fuel temperature in the hot channel is $537^{\circ} \mathrm{C}$, the maximum void fraction exceeds $20 \%$ in the hot channel at the nominal power $2 \mathrm{MW}$ and it reaches $16 \%$ in the average channel at the nominal power. These values are higher than the normal acceptable limits, and indicate that natural convection is probably not adequate for the power [5]. However, the finding is differernt from the Bock et al. which found that, in the TRIGA Mark Iireactor, the pool water provides sufficient natural convection cooling for operation up to $2 \mathrm{MW}$, or up to $3 \mathrm{MW}$ with a down-flow forced cooling [6].

The minimum DNBR for the TRIGA IPR-R1 (8.5) is much larger than other TRIGA reactors.
Meanwhile, McClellan TRIGA $2 \mathrm{MW}$ has DNBR = 2.5 as calculated by Jensen and Newell (1998). Bangladeshi TRIGA $3 \mathrm{MW}$ has DNBR $=2.8$. The power reactor is projected to operate at a minimum DNBR of 1.3 , while in routine operation it is operated at DNBR approaching 2 [4].

DNBR in the TRR-1/M1 reactor heat channel was analyzed using the COOLOD-N2 code. If DNBR is the only consideration, TRR-1/M1 can be operated up to $1.7 \mathrm{MW}$ without violating DNBR design criteria, which is 2.0. For the maximum allowable power of TRR-1/M1 at $1.5 \mathrm{MW}$, the maximum fuel temperature is $552^{\circ} \mathrm{C}$ and the minimum DNBR is 2.43 without bulk boiling in the core and allow approximately $15 \%$ thermal safety margin based on the nominal operating power of $1.3 \mathrm{MW}$ [7].

The Kyoto University Research Reactor has slightly different criteria. The following safety criteria for anticipated operational transients in KUR cores are (1) Minimum DNBR (viz. CHFR (critical heat flux ratio)) is greater than 1.5, (2) Maximum temperature in fuel meat is less than $400^{\circ} \mathrm{C}$, and (3) No boiling occurs in the core [8].

Based on the studies performed by General Atomics, TRIGA reactors can safely operate until approximately the specific power of $30 \mathrm{~kW} /$ fuel element, which assures that DNBR is above 1.0. The calculations are carried out for up to the pool temperature of $\sim 50^{\circ} \mathrm{C}$. Another important factor for the safe operation of the TRIGA reactors is the flow oscillations prior to CHF. This phenomenon is defined as the flow rate oscillation (increase and decrease of coolant flow rate in a cyclic fashion) in subcooled boiling [9].

DNBR of the Moroccan TRIGA Mark II is calculated based on the hot channel axial distribution of peaking factors. The hot channel axial DNBR distributions at 2.24 MW (112\% power) were calculated by PARET and COOLOD codes. Using COOLOD code, DNBR varies over the length of hot channel, starting from 7.83 to 5.56 , with a minimum of 2.97 around the axial center of the fuel element. Whereas when using PARET code, the MDNBR reaches the value of 4.17 , which is considerably far from safety limit on this parameter [10]. For PWRs, the resulting thermal design limit is expressed in terms of the minimum DNBR factor (MDNBR $\geq 1.3$ at $112 \%$ power) $[10,11]$. For fuel safety, it is recommended that the DNBR for TRIGA reactors is above 1.0, while for commercial PWRs the minimum design value is 1.3 [11].

An important conclusion in the study conducted by Haag and Levine is the fact that subcooled boiling occurs in the Pennsylvania State 
Breazeale Nuclear Reactor at relatively low reactor powers, i.e., $<200 \mathrm{~kW}$, in the centermost positions of the core [12].

In NUREG-1537, it is stated that a minimum CHF ratio of at least 2.0 is recommended for reactors with engineered cooling systems. TRIGA reactors with natural-convective cooling do not have engineered cooling systems. Past and current practice do not include hot channel factors or other uncertainty factors in the CHF analysis of TRIGA reactors that are cooled by natural convection. The possible exception here is the uncertainty in measured power [13].

TRIGA reactors that rely on natural convection for primary flow are among the most common research reactors in the US. Since these reactors can operate with subcooled nucleate boiling during normal operation, the margin to CHF can be a limiting safety design criterion and a limitation for power production [13, 14].

West et al explain that core can be cooled by natural convection cooling to power levels up to about 1.5 MW without any observable power fluctuations. Between 1.5 MW and 1.75 MW, depending upon the bulk water temperature, power fluctuations begin to appear. This "power chugging" is caused by the negative void coefficient acting through voids caused by local boiling in the region of minimum spacing between fuel rods at the high power locations in the core. Power "chugging" is a positive safety feature since it occurs prior to departure from nucleate boiling (DNB) which could cause very severe problems. "Power chugging" is such a strong, negative reactivity producing phenomenon that it may, in fact, prevent DNB from causing core damage. "Power chugging" has been studied extensively in TRIGA cores $[9,13,15]$.

Nazar and Pane stated that the operation of the Bandung TRIGA 2000 reactor at the power of 500 $\mathrm{kW}$ using 105 fuel elements, bubbles began to form as a boiling sign [16], while Nailatussaadah et al have calculated the criticality of the Bandung TRIGA 2000 reactor in four core configuration scenarios with two different methods, namely the compacting method based on the fuel burnup and the compacting method based on fuel density. The first scenario resulted in core criticality with effective multiplication factor of 1.01243 and radial power peaking factor of 1.655 . The second scenario resulted in core criticality with effective multiplication factor of 1.02031 and radial power peaking factor of 1.675935 [2].

The purpose of this study is to analyze the reactor power as a function of the number of fuel elements (105, 110, and 115 fuel elements) and
PPF (1.55, 1.65, 1.75, 1.85, and 1.95), especially those related to the safety of reactor fuel elements including DNBR, so that the analysis results can be used as a reference to determine at what power level the reactor can be operated safely.

\section{THEORY}

The fuel of TRIGA reactors uses stainless steel cladding and were designed to operate with nucleate boiling. During normal operation of TRIGA reactors, vapor bubbles are formed on some of the fuel rod surfaces while the mix-mean temperature of the adjacent coolant remains below the saturation temperature. Thus, there is some subcooled boiling, but no bulk boiling. The local agitation of the coolant caused by the nucleate boiling greatly enhances the heat transfer from the clad surface to the coolant stream. This helps to limit fuel rod surface temperatures. When these boiling conditions exist, the clad surface temperature will typically be no more than about $20^{\circ} \mathrm{C}$ higher than the local coolant saturation temperature. This temperature differential depends only on the local coolant pressure and local clad surface heat flux and does not depend on the local coolant flow rate [13].

A typical pool boiling curve, the Nukiyama curve (Fig. 1) is depicted in the heat flux log-log as a function of the superheat wall temperature, i.e. the difference between the cladding temperature and the saturation temperature $\left(\mathrm{T}_{\text {sur }}-\mathrm{T}_{\text {sat }}\right)$. At a low $\mathrm{dT}_{\text {sat }}$ value, the convective heat transfer coefficient curve is relatively linear (h) and constant, characterized by one-phase free convection, without the formation of bubbles. As the temperature rises, bubbles begin to appear and leave a hot surface, called the nucleate boiling. About ten to twenty degrees above the saturation temperature, the heat flux increases and the number of bubbles increases and reaches the surface. The transition boiling takes place between the nucleate boiling and the film boiling, also called partial boiling. Film boiling is characterized by the presence of a stable vapor layer that forms between hot and liquid surfaces. 


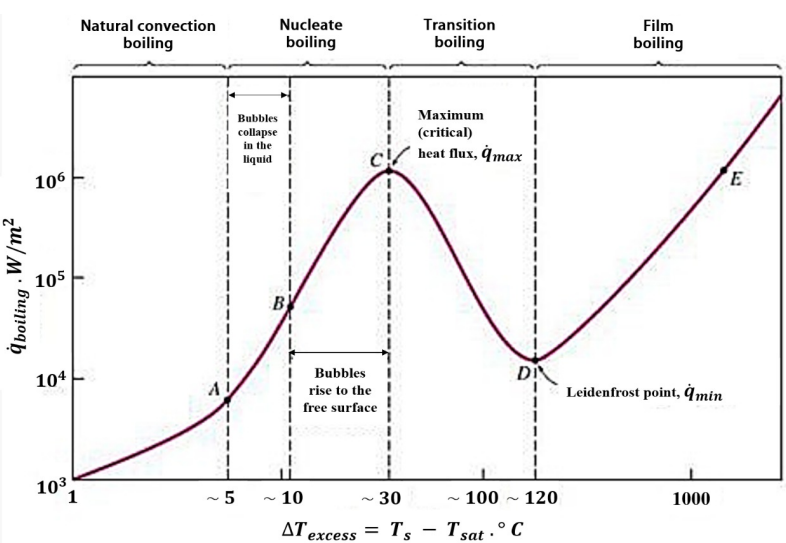

Fig. 1. Graphical representation of the general pool boiling curve showing CHF $[11,17,18]$

There are three transition points between the four boiling areas. The first point (A) is called the incipience of boiling (IB) or the onset of nucleate boiling (ONB), where bubbles first appear on a hot surface. The second point (C) is the peak of the curve in the nucleate boiling curve, called the departure from nucleate boiling (DNB), the critical heat flux (CHF), or peak heat flux. The last transition point (D) is located at the bottom of the film boiling regime and called the minimum boiling film point (MFB) or Leidenfrost point.

Subcooled boiling is characterized by the appearance of bubbles initiating from the heater surface while the bulk temperature is still below the saturation. During subcooled flow boiling, a high heat flux can be obtained with a relatively low wall superheat. Compared to saturated flow boiling, subcooled boiling has higher heat transfer efficiency and better CHF performance, which have been confirmed by many previous experimental investigations. As a result, subcooled boiling has a wide range of industrial applications, especially in nuclear power reactors [19].

Jazbec et al found that the void reactivity coefficient was negative for all conditions. This finding was supported by the calculations and experiments. The void reactivity coefficient is by far the largest when voids are formed close to the fuel region. As in the TRIGA reactor, the neutron flux is well thermalized. More than $90 \%$ of fission events are induced by thermal neutrons. The multiplication properties of such system are very sensitive to changes in moderator density, such as void formation [20].

\section{METHODOLOGY}

DNBR calculations using COOLOD-N2 software are performed using radial and axial power peaking factor data obtained from the neutronic calculation using the MCNP neutron transport code. From this calculation, the power distribution is obtained in each fuel element by varying each condition of the control rod withdrawal.

In this research, neutronic calculations on the reactor core are performed in configurations of 105 , 110, and 115 fuel elements with reference to the current conditions of the burnup. Other input data are listed in Table 1.

Table 1. Input data for thermalhydraulics calculations at the Bandung TRIGA 2000 reactor using COOLOD-N2

\begin{tabular}{|c|c|}
\hline PARAMETERS & VALUES \\
\hline Power, kW & $100-1000$ \\
\hline Number of fuel elements & $\begin{array}{l}105,110, \\
115\end{array}$ \\
\hline $\begin{array}{l}\text { Coolant temperature entering the reactor } \\
\text { core, }{ }^{\circ} \mathrm{C}\end{array}$ & 32 \\
\hline $\begin{array}{l}\text { Coolant pressure entering the reactor core, } \\
\mathrm{kg} / \mathrm{cm}^{2} \text { abs. }\end{array}$ & 1.69175 \\
\hline Geometry of fuel element: & \\
\hline Length, cm & 72 \\
\hline Equivalent diameter, $\mathrm{cm}$ & 1.8304 \\
\hline Diameter & 3.746 \\
\hline $\mathrm{Pitch} / \mathrm{D}$ & 1.162 \\
\hline $\begin{array}{l}\text { Resistance coefficient on the input side of } \\
\text { the fuel element }\end{array}$ & 1.3 \\
\hline $\begin{array}{l}\text { Resistance coefficient on the output side of } \\
\text { the fuel element }\end{array}$ & 0.3 \\
\hline Length of flow area, cm & 72 \\
\hline Loss coefficient due to laminar flow friction & 64.0 \\
\hline $\begin{array}{l}\text { The equivalent hydraulic diameter of the } \\
\text { reactor core, } \mathrm{cm}\end{array}$ & 25.1436 \\
\hline $\begin{array}{l}\text { The cross sectional area of the flow at the } \\
\text { input side of the reactor pool, } \mathrm{cm}^{2}\end{array}$ & 625.2075 \\
\hline $\begin{array}{l}\text { Sub channel area along the fuel element, } \\
\mathrm{cm}^{2}\end{array}$ & 2.694 \\
\hline $\begin{array}{l}\text { The cross sectional area of the flow at the } \\
\text { output side of the reactor pool, } \mathrm{cm}^{2} \\
\text { Power peaking factors: }\end{array}$ & 625.2075 \\
\hline $\mathrm{F}_{\mathrm{R}}$ & $\begin{array}{ll}1.55, & 1.65, \\
1.75, & 1.85 \\
1.95 & \end{array}$ \\
\hline $\mathrm{F}_{\mathrm{COOL}}, \mathrm{F}_{\mathrm{FILM}}, \mathrm{F}_{\mathrm{HFLX}}, \mathrm{F}_{\mathrm{CLAD}}, \mathrm{F}_{\mathrm{BOND}}, \mathrm{F}_{\mathrm{MEAT}}$ & 1.00 \\
\hline
\end{tabular}

\section{RESULTS AND DISCUSSION}

From the results of the neutronic calculation, the tendency of radial PPF is in the range of 1.55. $1.65,1.75,1.85$, and 1.95. Radial PPF on the reactor core is determined by arranging a certain core configuration and then calculated using MCNP. The axial PPF profile of the fuel element as shown in Fig. 2 was also calculated using the same code. 


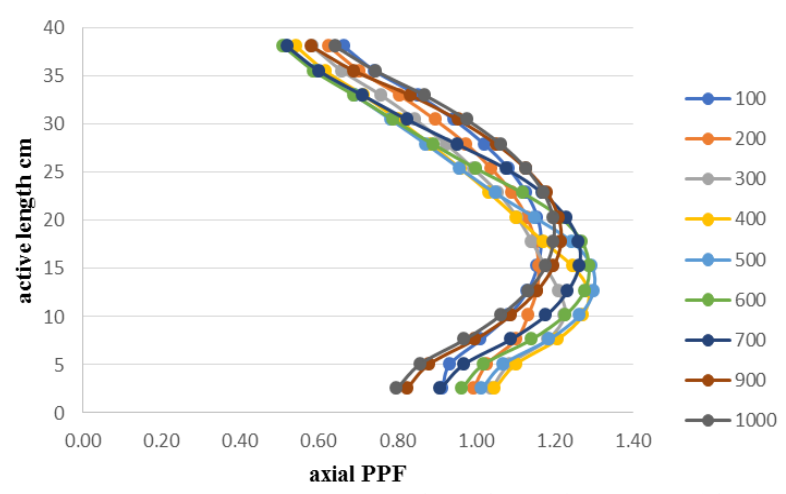

Fig. 2. TRIGA 2000 core axial peaking factor profile for each control element position from 0 to 1000

Calculation results using the COOLOD-N2 software are listed in Table 2 and Fig. 3.

Table 2. NBR on the number of fuel elements 105, 110, and 115 with PPF $1.95,1.75$, and 1.55

\begin{tabular}{cccccc}
\hline $\begin{array}{c}\text { Power } \\
\mathrm{kW}\end{array}$ & $\begin{array}{c}\text { DNBR } \\
\text { PPF 1.95 }\end{array}$ & $\begin{array}{c}\text { DNBR } 105 \\
\text { PPF 1.95 } \\
\text { FE 110 }\end{array}$ & $\begin{array}{c}\text { DNBR } \\
\text { PPF 1.95 } \\
\text { FE 115 }\end{array}$ & $\begin{array}{c}\text { DNBR } \\
\text { PPF 1.75 } \\
\text { FE 105 }\end{array}$ & $\begin{array}{c}\text { DNBR } \\
\text { PPF 1.75 } \\
\text { FE 110 }\end{array}$ \\
\hline 1000 & 0.91 & 0.94 & 0.97 & 1.01 & 1.05 \\
900 & 0.99 & 1.02 & 1.06 & 1.10 & 1.14 \\
800 & 1.08 & 1.12 & 1.15 & 1.20 & 1.25 \\
700 & 1.20 & 1.24 & 1.28 & 1.33 & 1.38 \\
600 & 1.35 & 1.40 & 1.44 & 1.50 & 1.56 \\
500 & 1.56 & 1.61 & 1.67 & 1.73 & 1.80 \\
400 & 1.86 & 1.92 & 1.99 & 2.07 & 2.14 \\
300 & 2.26 & 2.42 & 2.51 & 2.51 & 2.70 \\
200 & 3.07 & 3.18 & 3.29 & 3.42 & 3.55 \\
100 & 6.08 & 5.73 & 5.92 & 6.78 & 6.39 \\
\hline
\end{tabular}

\begin{tabular}{ccccc}
\hline & & & & \\
Power & DNBR & DNBR & DNBR & DNBR \\
$\mathrm{kW}$ & FE 115 & PPF 1.55 & PPF 1.55 & PPF 155 \\
& & & FE 110 & FE 115 \\
\hline 1000 & 1.08 & 1.15 & 1.19 & 1.22 \\
900 & 1.18 & 1.24 & 1.29 & 1.33 \\
800 & 1.29 & 1.36 & 1.41 & 1.46 \\
700 & 1.43 & 1.51 & 1.56 & 1.61 \\
600 & 1.61 & 1.70 & 1.76 & 1.82 \\
500 & 1.86 & 1.96 & 2.03 & 2.10 \\
400 & 2.22 & 2.34 & 2.42 & 2.51 \\
300 & 2.80 & 2.84 & 3.05 & 3.16 \\
200 & 3.67 & 3.87 & 4.01 & 4.15 \\
100 & 6.60 & 7.65 & 7.21 & 7.45 \\
\hline
\end{tabular}
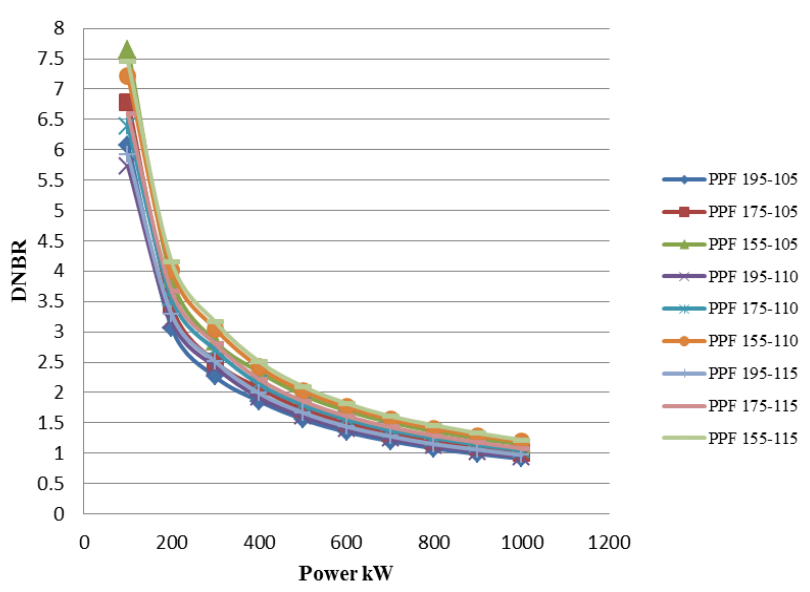

Fig. 3. DNBR as a function of power on the number of fuel elements 105, 110, 115 and PPF 1.55, 1.75, and 1.95
In Table 2 and Fig. 3, generally, it can be seen that the number of fuel elements is proportional to the DNBR value. Meanwhile, the higher the radial PPF value, the lower the DNBR value. At PPF of 1.95 and the number of fuel elements 105,110 , and 115 , at the power of $1000 \mathrm{~kW}$, the DNBR value is < 1 , while at PPF of 1.75 and 1.55 , on the number of fuel elements the values of 105, 110, and 115, DNBR value is $>1$. Because during normal operation, TRIGA reactor can operate with subcooled nucleate boiling, CHF can be used as a design limit criterion [13]. Based on the studies performed by General Atomics, the TRIGA reactors can safely operate until DNBR is above 1.0 [9], whereas in a commercial PWR, the minimum DNBR design value is $1.3[4,10,11]$. The TRIGA reactor fuel itself should have inherent safety characteristics even for fast reactivity insertion events. This special feature is enabled due to the large prompt negative temperature coefficient of reactivity of the $\mathrm{UZrH}$ fuel [6].

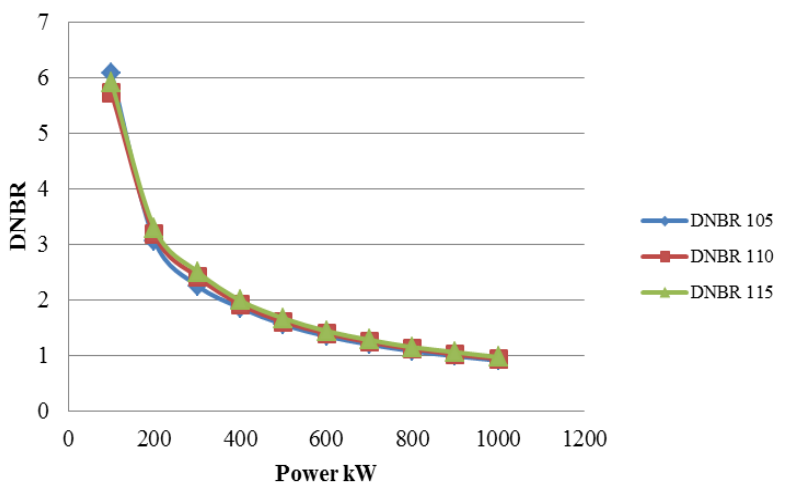

Fig. 4. DNBR as a function of power at PPF 1.95 and the number of fuel elements 105, 110, and 115

In Fig. 4, it can be seen that when DNBR 1.3 is used as a reference, then for PPF of 1.95 and the number of fuel elements 105,110 , and 115 are only feasible to operate at the power of $600-700 \mathrm{~kW}$.

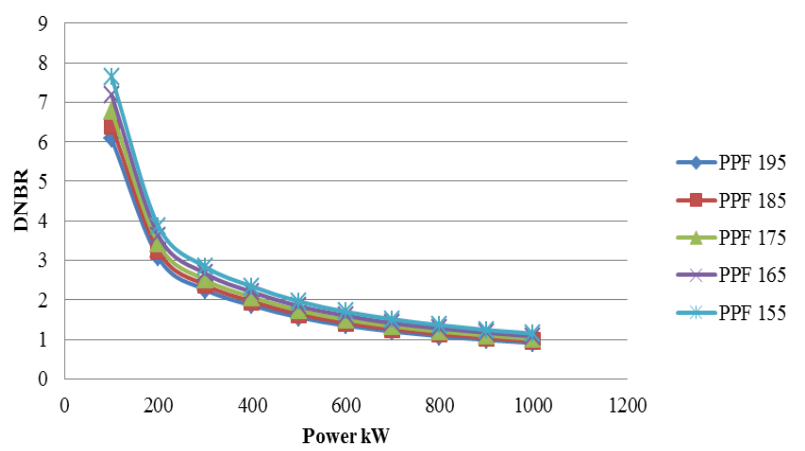

Fig. 5. DNBR as a function of power on PPF 1.55, 1.65, $1.75,1.85$, and 1.95 with the number of fuel elements of 105 
In the Fig. 5, it can be seen that for the number of fuel element at 105 and PPF at 1.55, DNBR value at power of $800 \mathrm{~kW}$ is 1.36 . Meanwhile, at PPF 1.75 and operating power of $700 \mathrm{~kW}$, the DNBR is 1.33 . In order to obtain DNBR $>1.3$ for PPF at 1.95 , the power must be decreased to 600 $\mathrm{kW}$.

Table 3. $\mathrm{dT}_{\text {sat }}$ and DNBR on PPF 1.95 and the number of fuel elements 105, 110, and 115

\begin{tabular}{ccccccc}
\hline $\begin{array}{c}\text { Power } \\
(\mathrm{kW})\end{array}$ & $\begin{array}{c}\mathrm{T}_{\text {CLAD }}-\mathrm{T}_{\mathrm{SAT}} \\
\text { EB 105 }\end{array}$ & DNBR & $\begin{array}{c}\mathrm{T}_{\text {CLAD }}-\mathrm{T}_{\mathrm{SAT}} \\
\text { EB 110 }\end{array}$ & DNBR & $\begin{array}{c}\mathrm{T}_{\mathrm{CLAD}}-\mathrm{T}_{\mathrm{SAT}} \\
\text { EB 115 }\end{array}$ & DNBR \\
\hline 1000 & 19.97 & 0.91 & 19.5 & 0.94 & 19.07 & 0.97 \\
900 & 18.93 & 0.99 & 18.48 & 1.02 & 18.05 & 1.06 \\
800 & 17.8 & 1.08 & 17.37 & 1.12 & 16.96 & 1.15 \\
700 & 16.57 & 1.2 & 16.17 & 1.24 & 15.79 & 1.28 \\
600 & 15.24 & 1.35 & 14.85 & 1.4 & 14.48 & 1.44 \\
500 & 13.73 & 1.56 & 13.36 & 1.61 & 13.01 & 1.67 \\
400 & 11.97 & 1.86 & 11.62 & 1.92 & 11.29 & 1.99 \\
300 & 9.97 & 2.26 & 9.49 & 2.42 & 9.17 & 2.51 \\
200 & 7.25 & 3.07 & 6.96 & 3.18 & 6.68 & 3.29 \\
100 & -3.15 & 6.08 & -5.9 & 5.73 & -9.02 & 5.92 \\
\hline
\end{tabular}

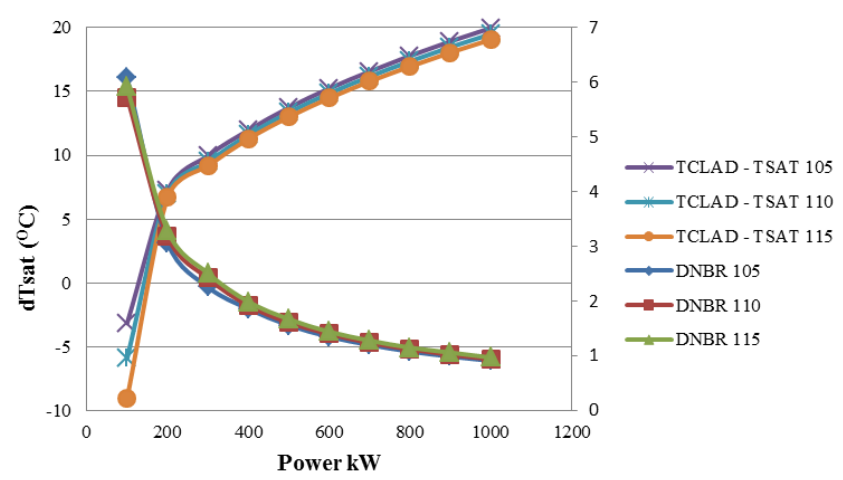

Fig. 6 . $\mathrm{dT}_{\text {sat }}$ and DNBR as a function of power and the number of fuel elements 105,110 , and 115 with PPF at 1.95

In the Nukiyama curve (Fig. 1), CHF occurs at $\mathrm{dT}_{\text {sat }}$ of $30^{\circ} \mathrm{C}$, whereas boiling conditions exist usually at the clad surface temperature of no more than about $20^{\circ} \mathrm{C}$ higher than the local coolant saturation temperature [13]. In Table 3 and Fig. 6, it can be seen that at power $>900 \mathrm{~kW}$, even though $\mathrm{dT}_{\text {sat }}$ is still rated at $18^{\circ} \mathrm{C}$, the DNBR value is $<1$. At $\mathrm{DNBR}$ value $\approx 1.3, \mathrm{dT}_{\text {sat }} \approx 15^{\circ} \mathrm{C}$. In this condition, nucleate boiling has occurred.

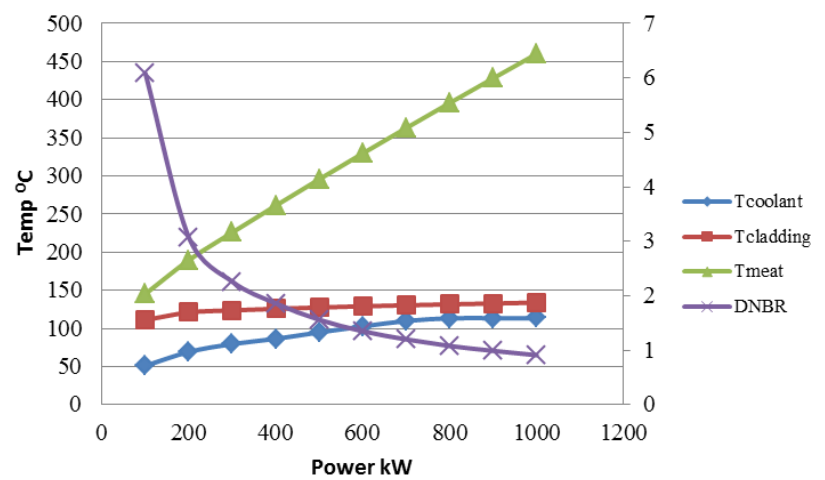

Fig. 7. DNBR and temperature as a function of power on the number of fuel elements 105 and PPF at 1.95

In normal operation at a power of $1000 \mathrm{~kW}$, the number of fuel elements is 105 with PPF at 1.95 as in Fig. 7, the obtained calculation results using COOLOD-N2 are the following. The cladding temperature is $133.86^{\circ} \mathrm{C}$ and the meat temperature is $460.06^{\circ} \mathrm{C}$. As explained in the Bandung TRIGA 2000 Reactor Safety Analysis Report, the highest allowed fuel temperature is $1150^{\circ} \mathrm{C}$ if the cladding temperature of the fuel element is below $500^{\circ} \mathrm{C}$. However, if the cladding temperature is equal to the temperature of meat (such as when a loss of coolant accident occurs or when the reactor cooling water reaches boiling film conditions), the fuel temperature must not exceed $950^{\circ} \mathrm{C}$.

\section{CONCLUSION}

Calculations of DNBR, $\mathrm{dT}_{\text {sat, }}$ cladding and meat fuel element temperature of the Bandung TRIGA 2000 reactor on the number of fuel elements 105,110 , and 115 with PPF $1.55,1.75$, and 1.95 have been carried out using Coolod-N2 and MCNP software. The results of the calculation can be used as a reference in determining the limits of Bandung TRIGA 2000 operational power, by considering the inherent safety system of the TRIGA reactor that is negative void reactivity. For example, if DNBR $\approx 1.3$ is taken as a safety limit for reactor operation, then at PPF $1.95(105,110$, and 115 fuel elements), it can be considered to operate the reactor at $600-700 \mathrm{~kW}$. However, if $\mathrm{PPF}$ is 1.75 , the reactor can be operated at $700-800$ $\mathrm{kW}$, while if the PPF is 1.55 , the reactor can be considered for operation at $800-900 \mathrm{~kW}$. It should be remembered that at the DNBR 1.3, nucleate boiling has occurred because $\mathrm{dT}_{\text {sat }}>10^{\circ} \mathrm{C}$. 


\section{ACKNOWLEDGMENT}

The authors would like to express special thanks to the Center for Applied Nuclear Science and Technology which has supported this work through the DIPA PSTNT in 2015-2019. Also thanks to friends in the Reactor Division for their support.

\section{REFERENCES:}

1. Sudjatmi K.A.; Endiah Puji Hastuti; Surip Widodo; Reinaldy Nazar. Analysis of natural convection in TRIGA reactor core plate types fueled using COOLOD-N2 (in Indonesian). Tri Dasa Mega. 2015. 17:67-78.

2. Nailatussaadah, Basuki P., Sudjatmi K. Analysis of TRIGA 2000 Core Reshuffling Scenario Based on Fuels Burn up and Fuels Density. J. Phys.: Conf. Ser. 2020. 1436:012049.

3. Noname LAK TRIGA 2000. 2016.

4. Mesquita A.Z., Palma D.A.P., Costa A.L., Pereira C., Veloso M.A.F., Reis P.A.L. Experimental Investigation of Thermal Hydraulics in the IPR-R1 TRIGA Nuclear Reactor. in: Nuclear Reactors. 2012.

5. Erradi L., Essadki H. Analysis of safety limits of the Moroccan TRIGA MARK II research reactor. Radiat. Phys. Chem. 2001. 61(36):777-9.

6. Böck H., Villa M., Bergmann R. Five Decades of TRIGA Reactors. 25th Int. Conf. Nucl. Energy New Eur. 2016.(2016):1-8.

7. Tiyapun K., Wetchagarun S. Neutronics and thermal hydraulic analysis of TRIGA Mark II reactor using MCNPX and COOLOD-N2 computer code. J. Phys.: Conf. Ser. 2017. 860(1)

8. Shen X., Nakajima K., Unesaki H., Mishima K. Reactivity insertion transient analysis for KUR low-enriched uranium silicide fuel core. Ann. Nucl. Energy. 2013. 62:195-207.

9. Noname Safety analysis report University of UTAH Nuclear Reactor Facility. 2010.

10. Boulaich Y., Nacir B., El Bardouni T., Zoubair M., El Bakkari B., Merroun O., et al. Steadystate thermal-hydraulic analysis of the Moroccan TRIGA MARK II reactor by using PARET/ANL and COOLOD-N2 codes. Nucl. Eng. Des. 2011. 241(1):270-3.

11. Babitz P.M. Thermalhydraulics analysis of the UTAH TRIGA Reactor. 2012.(December)

12. Haag J.A., Levine S.H. Thermal analysis of the Pennsylvania State University Breazeale nuclear reactor. Nucl. Technol. 1973. 19(1):615.

13. Feldman E.E. Fundamental Approach to TRIGA Steady-State Thermal-Hydraulic CHF Analysis. Argonne Natl. Lab. 2007.:1-49.

14. Avery M., Yang J., Anderson M., Corradini M., Feldman E., Dunn F., et al. Critical heat flux in TRIGA-fueled reactors cooled by natural convection. Nucl. Sci. Eng. 2012. 172(3):249-58.

15. Gordon B. West and Robert H. Chesworth Update on world-wide use of TRIGA-LEU fuel including loss of flow test. Proc. Int. Meet. Reduc. Enrich. Res. TEST React. Newport, Rhode Isl. Sept. 23-27, 1990. 1990.(1990)

16. Nazar R., Pane J.S. Steady-state Thermalhydraulic Analysis of the TRIGA 2000 Reactor Core when Using Configuration of 105 Fuels. J. Phys.: Conf. Ser. 2020. 1436:012091.

17. Juarsa M., Koestor R.A., Setiadi N., Putra D., Antariksawan A.R., Mulyana C., et al. Heat flux calculation for boiling curve during quenching experiment using heated hollow cylinder (in Indonesian). Tri Dasa Mega. 2010. Vol 12(3):67-74.

18. Wargon M. Safety analysis of the new coremoderatos assembly for the PENN STATE BREAZEALE Nuclear Reactor. A Thesis Nucl. Eng. 2015.(August 2015)

19. Yan J., Bi Q., Liu Z., Zhu G., Cai L. Subcooled flow boiling heat transfer of water in a circular tube under high heat fluxes and high mass fluxes. Fusion Eng. Des. 2015. 100:406-18.

20. Jaz A., Snoj L., Kavšek D. Analysis of a Void Reactivity Coefficient of the JSI TRIGA Mark II Reactor. in: 22nd International Conference Nuclear Energy for New Europe. BLEDSLOVENIA. 2013. pp. 606.1-606.9. 